helse- og sosialpersonell, både studenter og klinikere. Imidlertid er Kroppskunnskaping et registrert og beskyttet varemerke, og det er knyttet vilkår til bruk av konseptet i praksis (www.kunnskaping.no).

Sissel Steihaug

Avdeling for helsetjenesteforskning SINTEF

Oslo

\section{Ikke bare jeg?}

Eggen I.

\section{Bare jeg..}

En dissosiativ identitetsforstyrrelse. $355 \mathrm{~s}$ Stavanger: Hertervig forlag, 2008. NOK 149 ISBN 978-82-8216-025-4

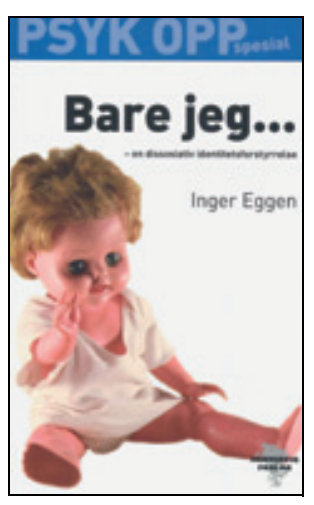

Inger Eggen gir oss en sterk, ærlig og gripende beretning om en oppvekst og en personlighetsutvikling med en selvopptatt mor, en hatefull bror og - verst av alt - en alkoholisert og overgripende far. Bare jeg... er utgitt i serien til stiftelsen Psykiatrisk Opplysning og er således ment å bidra til mer åpenhet omkring psykiske lidelser, og ikke minst å gi alvorlige tilstander, i dette tilfellet en dissosiativ identitetsforstyrrelse, et ansikt. Det gjør Eggen til gagns og på en så overbevisende måte at man som leser sitter igjen med inntrykk av at det i tillegg til det dissosiative også foreligger en multippel personlighetsforstyrrelse. For det er et omfattende personlighetsgalleri som vi blir kjent med og som befolker hennes hage, utgjør forskjellige deler av henne og tar styringen over hennes atferd i ulike situasjoner.

At forfatteren har hatt behov for å «skrive seg igjennom» sin lidelse, er fullt forståelig, og hun nærmest tømmer ut sitt sjeleliv i usensurert form fra side til side. I det ligger noe av vanskeligheten $i$ å gi en anmeldelse en balansert og «rettferdig» form. Som leser kan man få følelsen av aldri å bli ferdig, mye av det samme gjentar seg - med de indre dialogene i en kaotisk form, som naturlig nok avspeiler hennes følelses- og tankeliv, men som kan virke noe utmattende på undertegnede.

Når det er sagt, skal Eggen ha ros for å ha gitt sitt bidrag til avsløringen av det besteborgerlige fasadespill som omgir for mange familier i vårt samfunn og som i all sin tilsynelatende vellykkethet produserer en slik tragedie for et barn.

Budskapet er derfor rettet til allmennheten - uansett profesjon. Det er verdifullt og bevisstgjørende og fortjener oppmerksomhet, men formen kan gjøre at noen faller av lasset underveis. Holder man imidlertid ut til slutt, făr man belønning gjennom det glimtet av håp som forfatteren ser og vil dele med oss i de siste setningene: «... med hjelp til å forstå min indre verden for å akseptere skadene som ble påført meg som barn, kan jeg en gang oppnå å dirigere personene i hagen min. Det er mulig at vi kan spille sammen og lytte til hverandre. Det kan bli kvinnen med navnet Inger. En gang. Det er visst mulig å erkjenne at livet ble slik det ble, finne nye toner og ny musikk som kan gi mening og glede. For meg. For Inger. Kanskje.»

Med dette håp for øye og i takknemlighet til sine terapeuter, uttrykt i forordet, kan Eggen makte å fri seg fra dissosiasjonen og ta herredømme over de multiple personlighetene som har befolket hennes hage - for dermed endelig å kunne spille på lag med seg selv.

\section{Tore Gude}

Modum Bad

Vikersund

\section{Likeverdig samarbeid i psykiatrien}

Storm M.

Brukermedvirkning i psykisk helsearbeid

156 s, tab, ill. Oslo: Gyldendal Akademisk, 2009. Pris NOK 235

ISBN 978-82-05-39166-6

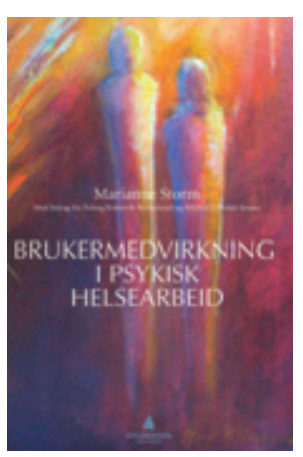

Hensikten med boken er å gi konkrete innspill til arbeidet med brukermedvirkning i et samarbeid mellom pasienter, deres pårørende, brukerrepresentanter og helsepersonell innen psykisk helsevern. Forfatteren er sykepleier med grunnfag og mellomfag i psykologi og hovedfag i helsefag. Boken har bidrag fra Åslaug Botnevik Rennesund, som har mastergrad i psykologi, og Målfrid J. Frahm Jensen som er hjelpepleier, lyriker og skribent.

De nye helselovene bereder grunnen for en ny måte å samarbeide på, der pasientene ikke lenger er passive mottakere av ekspertenes anbefalinger og råd, men der det stilles sterkere krav til den informasjon som skal gis av helsepersonell og ikke minst den innflytelse pasientene skal ha på sin egen behandling. I psykiatrien kan dette være spesielt vanskelig, men her balanseres det fornuftig i boken, der det understrekes at tilnærmingen må være fleksibel og tilpasses pasientens tilstand til enhver tid. Siktemålet er å ansvarliggjøre pasienten og sette verdiene autonomi og selvstendighet i fokus. Pårørende har også en viktig rolle, og det gis anbefalinger for hvordan de best kan tas med $i$ arbeidet rundt pasienten og samtidig bli ivaretatt med sine individuelle behov.

I boken gjennomgås et konkret og praktisk opplegg av ti måneders varighet, med utgangspunkt i hovedforfatterens og de øvrige bidragsyternes erfaringer fra avdelinger i Stavanger og Ryfylke distriktspsykiatriske senter. Det beskrives en innledende kartleggingsfase med etablering av styringsgruppe, dialogkonferanse (seminar), personalmøter med bruk av ekstern fasilitator (et bedre ord enn veileder i denne sammenhengen), arbeid i temagrupper, undervisningsopplegg med faglig påfyll (kunnskapsforum), og det gis en del tips om hvilke fremgangsmåter som kan være nyttige når grupper går i stå og ikke kommer videre. Til sist gis det innspill som kan være hensiktsmessige for å kartlegge om opplegget har gitt noen effekt, og som kan være utgangspunkt for videre oppfølging.

De konkrete beskrivelsene er nyttige, men boken skjemmes av for mange gjentakelser og selvfølgeligheter. Slik sett hadde et mer kortfattet hefte vært mer anvendelig i praksis. Likevel kan den trygt anbefales for de miljøer som ønsker en ledesnor for sitt arbeid på dette viktige feltet.

\section{Stein Opjordsmoen}

Avdeling for forskning og undervisning

Oslo universitetssykehus, Ullevål

\section{Godt om inneklima}

\section{Aas K.}

\section{Godt inneklima}

Håndboken for hjemmet. 302 s, ill. Oslo:

Cappelen Damm, 2009. Pris NOK 299

ISBN 978-82-02-29065-8

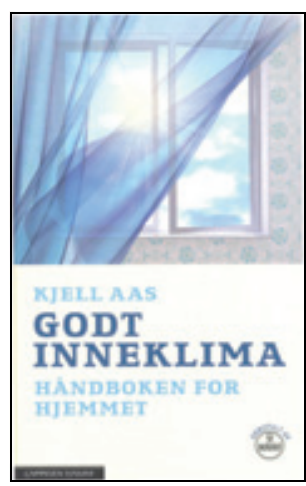

De senere årene har det vært stadig økende oppmerksomhet på inneklima. Økt kunnskap har gjort det viktig å erkjenne at inneklima er viktig for både helse og trivsel. Det er imidlertid mange aktører på banen, og for folk flest kan det være forvirrende å finne ut av hvor man skal hente nyttig informasjon.

Kjell Aas er en kjent og dyktig fagperson innenfor det norske inneklimafeltet. Her har 
han skrevet en bok som nok først og fremst er beregnet på personer som ikke har mye kunnskap om feltet fra før. Forfatterens innfallsvinkel er preget av hans lange yrkesliv som kliniker og rådgiver overfor barn med astma og deres foreldre. Han ønsker å formidle viktig kunnskap om kroppens reaksjoner samtidig som han gir praktiske råd om hva man kan gjøre for å bedre forholdene i barns innemiljøer for at de skal bli mindre belastet med uheldige påvirkninger. Bokens fortrinn er at Kjell Aas ser dette komplekse feltet fra pasientenes side.

Forfatteren går grundig til verks. Innledningen er en generell og leservennlig gjennomgang av en del begreper og temaer, som hvorfor inneklimaet er viktig, kroppens interaksjoner med de kjemiske stoffene vi kan eksponeres for, belastninger og tålegrenser samt overfølsomhet og allergi. Videre omtaler han begreper som miljøintoleranse og miljøhemning, som i stor grad er subjektive tilstander der entydige medisinske diagnoser ikke er mulig å stille. Dette omtales på en ryddig måte. Hvordan man skal håndtere denne type symptomer er nok omstridt i fagmiljøene, men forfatterens synspunkter er et nyttig innspill til hvordan man kan se på slike tilstander. En liten innvending er at denne delen blir noe omfattende før man kommer videre til selve inneklimaproblematikken. På den annen side angir forfatteren at boken ikke behøver å leses fra perm til perm, men at man heller leser de temaene man interesser seg mest for.

Videre omtales de vanligste inneklimaforhold, bl.a. fukt, muggsopp og partikkelforurensning, som for en del kan forårsake helseplager eller nedsatt trivsel, og hvilke tiltak man kan gjøre for å bedre inneklimaet. Det siste inkluderer såkalt kvalifisert skjønn, en metode forfatteren har utviklet for å kunne med relativt enkle midler vurdere inneklimaforhold på et gitt sted. Videre inneholder boken råd om bl.a. rengjøring, ventilasjon, bruk av luftrensere og ev. nytte av inneklimamålinger, vedlikehold, oppussing og nyanskaffelser. Samlet sett synes jeg temaene er behandlet på en grundig og lettlest måte. Boken kan derfor anbefales til dem som vil ha en innføring i inneklimaproblematikk og mulige løsninger.

\section{Rune Becher}

Nasjonalt folkehelseinstitutt

\section{På lag med sykdommen}

Seljeskog T.

Å leve med akutt intermitterende porfyri

En personlig beretning. 91 s, ill. Levanger:

Tove Seljeskog, 2009

Pris NOK 250 + porto NOK 30

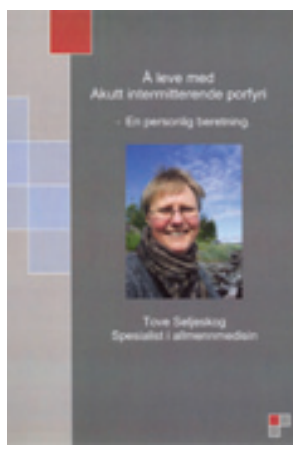

Forfatteren er 44 år allmennpraktiker i Levanger og tobarnsmor. Fra hun var tenåring fikk hun hodepine og tiltakende plager med magen. Først da hun var 36 år fikk hun diagnosen akutt intermitterende porfyri (AIP). Moren har samme sykdom.

Porfyriene er sjeldne. Det er kanskje 300 pasienter i Norge. De er autosomalt dominant arvelige og forekommer i seks forskjellige former i Norge, avhengig av hvilket enzym i produksjonskjeden for hem som er rammet. Kvinner har mer plager enn menn, fordi symptomene er delvis hormonavhengige. Symptomene kommer i anfall. Når sykdommen er så sjelden og så variabel, er det ikke mange leger som er oppdatert på den.

Det er en vanskelig kunst å skrive en bok «om meg selv og sykdommen min». Den må være personlig og detaljert, og det er vanskelig å passe grensene. Den må ikke bli så personlig at den krysser grensen til det private, og den må heller ikke virke selvopptatt og selvsentrert.

Forfatteren kommer nok nær disse grensene, men jeg synes hun klarer den balansekunsten. Viktige hjelpemidler er humor og nydelige naturfotografier. Hun har to viktige budskap. Det ene er å formidle kunnskap om denne sjeldne sykdommen som de fleste leger aldri ser. Det andre er å forklare sine egne mestringsstrategier. Det nytter ikke å kjempe mot sykdommen. Det bare erter den opp og forverrer plagene, fordi stress utløser anfall. Derfor må hun forstå sykdommen sin og spille på lag med den. Hun minner meg nesten om Alexander Kielland som sa: «Jeg oppfatter mine sykdommer som vennlige losjerende!» Porfyri er ikke akkurat vennlig, men den kan ikke nedkjempes. Derfor må den mestres, og hun klarer tydeligvis å være alt: sykdomsbærer, allmennpraktiker (riktignok redusert jobb), mor, husmor og forfatter - imponerende!

Hun skriver godt og gir praktiske råd ned til de minste detaljer. Poenget er nettopp at man hele tiden må være litt foran sykdommen, forebygge anfall og samtidig kunne håndtere dem når de kommer. Perfeksjonistene klarer seg bedre med denne sykdommen enn slappfiskene. Hvem bør så lese denne boken? Pasienter med akutt intermitterende porfyri bør selvfølgelig gjøre det, og det bør også leger som har slike pasienter. Her kan kanskje mange leger lære noe om holdninger til kronisk syke pasienter.

Peter F. Hjort

Blommenholm

\section{Ode til den offentlige hest}

Olsen SM.

Hestekrefter i offentlig tjeneste

462 s, ill. Oslo: Tun forlag, 2008. Pris NOK 549

ISBN 978-82-529-3209-6

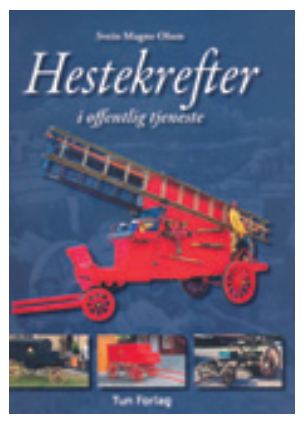

Det moderne Norge tok stort sett form i hundreårsperioden 1850-1950. Det meste vi har av infrastruktur kom på plass da. Det er derfor interessant at denne storstilte oppbyggingsperioden også faller innenfor den tiden

da hesten var den selvfølgelige arbeidskamerat. Hestens trekkraft dimensjonerte svært mye, fra landverts transporttider til gjennomførbarheten for større anlegg. Selv om mange hesteredskaper hadde tradisjoner langt bakover i historien, ble det også konstruert nye som var tilpasset nye innsatsområder, f.eks. veiskraper og pudrettvogner - eller den sledegående bussen fra Trondheim. Det meste av dette er for lengst ute av bruk, mye er borte og glemt nå, men det er likevel en viktig del av vår kulturarv.

Svein Magne Olsen har lagt ned et stort arbeid for å dokumentere hesteredskaper, og dette er en av hans bøker om dette. Her reiser han et monument over hesten i offentlig tjeneste, den navnløse forutsetningen for utviklingen gjennom en lang periode. Han har tatt for seg de ulike samfunnsfeltene, brannvern, forsvar, jernbane, post, telekommunikasjon osv. Helse har f.eks. fått et meget velskrevet 40 siders kapittel.

Det er ofte en svakhet ved historiefremstillinger av enkeltfelt at sammenhengen med konteksten blir for utydelig. Her er det snarere omvendt. Ofte er konteksten så fyldig og leseverdig at hesten trer i bakgrunnen - den ser bare traust på oss fra bildene. Forfatteren har kombinert det å skrive god historie med å lage en tiltalende bok som mange sikkert gjerne lar ligge fremme.

Illustrasjonsmaterialet er meget godt. Fotografier og kunstreproduksjoner er delikat gjengitt, og bokutstyret for øvrig er tilsvarende.

Dette må være den ideelle gavebok ikke bare til dem som er glad i hester, men 